\title{
Social Networks, Place Attachments and Mexican Urban Migration
}

\author{
By Cristóbal Mendoza*
}

\begin{abstract}
By using qualitative data and a representative survey of Valle de Chalco-Solidaridad, a municipality on the periphery of Mexico City, this article provides fresh information on urban migration to the U.S. and the role of social networks in urban settings. The article critically reviews previous theoretical assumptions about the nature of Mexican migration regarding the role of social networks in organizing migration flows that were largely based on rural-origin datasets and case studies. The article demonstrates that variations on the socio-demographic profile of the would-be emigrants of the US are found depending on the household's social networks. In other words, not everyone is susceptible to emigration, despite structural adjustments in the economy and a general landscape of relative privation. Our data suggests that urban females may organize their own autonomous social networks, the higher educated in cities value their future in Mexico (and only try the adventure further north when they have the support of social networks), and the irrelevance of territorial attachments for understanding urban migration from Mexico.
\end{abstract}

Keywords: Mexico City, Mexico-US migration, Place social networks, Urban migration.

\section{Introduction}

The increasing proportion of urban migrants in Mexican international outflows has largely been documented in literature (e.g. Roberts et al. 1999, Marcelli and Cornelius 2001). This has concluded that economic crises have badly hit the middle classes and triggered migration from Mexican cities, due to the worsening of the living standards of the urban middle classes, particularly after the entry of Mexico into NAFTA in 1994 (Delgado-Wise and Márquez Covarrubias 2007). However, for other scholars there are no obvious linkages between crises and other sources of structural changes, and outmigration in urban settings (as it is in rural Mexico, Hernández-León 2008).

What literature has partially done so far is to explore the role of social networks for explaining urban migration to the USA. The bulk of the empirical research on migrant social networks between Mexico and the US has mainly been constructed from evidence from the States, and rural and small cities in Mexico. However, a growing body of literature on urban migration from Mexico to the US that has emerged slowly but decisively since the 1990s has challenged previous theoretical assumptions about the nature of Mexican migration regarding the role of social networks (e.g. Roberts et al. 1999, Fussell and Massey 2004, Hernández-León 2008, Mendoza 2009). Yet studies

*Human Geographer, Department of Sociology, Metropolitan Autonomous University (UAM), Mexico. 
on urban migrant ties are newer compared to the wealth of knowledge about rural migration and so far, results stemming from both quantitative and qualitative methodologies are inconclusive.

These studies have suggested that migrant social networks are less dense and more specialized in cities than in the countryside (Flores et al. 2004, Hernández-León 2008), thus urban migrants are more likely to be either permanent or temporary in the US (instead of creating transnational links, as rural migrants are supposed to do; Roberts et al. 1999). Using Mexican Migration Project data, it has been demonstrated empirically that urban dwellers rely on kinship contacts to support US migration yet do not resort to friendship and (non kin) networks that are based on Mexico's previous residence (Flores et al. 2004). Furthermore, it seems that many of the social networks of the Mexican urban migrants in the US have their roots in their rural origins, building up complex routes in which cities are just a step toward international migration (Rivera-Sánchez 2007, López and Runsten 2004). Without strong ties, urban settings do not provide the conditions for the expansion of social networks, so preventing the consolidation of self-sustained international flows and cumulative causation (Fussell and Massey 2004). In this sense, the Hernández-León (2008) research on the Houston-Monterrey circuit reckons that these urban residents combine a mix of strong family networks with weak ties that are supported by friends and neighbours in the place of residence.

This literature indicates that the networks of urban migrants operate differently from those built in Mexico's rural settings. Explaining these differences, some scholars point to the more recent character of migrant urban networks (Flores et al. 2004), the "rural" origins of many urban migrants that eschew the construction of a sense of community in Mexican cities (López and Runsten 2004), the lack of trust in self-perceived violent contexts as the main reason for deterring information exchange in large Mexican cities (Mendoza 2009) and the individual values that are supposedly dominant in urban settings (Roberts et al. 1999, Hernández-León 2008).

These explanations give an idea about the reasons the urban social networks of migrants are weak and mainly structured along family and household lines. However little is known about the circumstances and the mechanisms of how social networks play a role in increasing the probability of international migration from urban Mexico. Stemming from the literature, here it is assumed that networks are organized following family and household lines (and not constructed at a community level), so we would expect that the households with international ties would behave in a different way from those without these connections. Furthermore, since urban ties are less dense and more specialized than rural networks, one may think that these ties and contacts are more likely to be organized around specific lines and subgroups in urban settings (as is the case with industrial blue collar workers in the Monterrey-Houston circuit, Hernández-León 2008). The weakness of social networks eventually raises the economic costs of migration, and prevents the expansion of migration to the less educated groups (Massey et al. 1987, 
McKenzie and Rapoport 2007). If this is true, we may expect a positive selection in the out-migration flows toward the better educated in urban settings.

In this context, this article focuses on the international migration out-flows from Valle de Chalco-Solidaridad, a municipality which is part of the Mexico City Metropolitan to the US. Valle de Chalco-Solidaridad is a very recent urban space that has been built on a lake bed that was drained only a few decades ago. This municipality has experienced a remarkable growth in its international migration figures, and it can be seen as an example of contemporary migration out-flows from urban Mexico. The municipality has grown as a consequence of internal migration flows, with its population increasing dramatically, from 219,773 in 1990 (Lindón 1999) to 357,645 inhabitants in 2010 (INEGI 2013). Thus, a "classical" process of suburbanization and peri-urbanization of Mexico City, with the poor that is put aside to isolated peripheries (Aguilar 2002), co-exists in the municipality with a diminishing process of urban-rural migration and increasing international out-flows to the USA.

By using quantitative and qualitative methods, the article reveals information about the functions and dynamics of urban social networks that are constructed by migrants as compared to rural-based migrant networks in the municipality. It also explores whether and, to what extent, territorial and place attachments are relevant in understanding social network formations. The article takes into account the theoretical framework of social networks in migration processes and sheds light, from a different angle, on a classical theory that has mainly been tested in rural settings in Mexico. The article also takes a geographical stance, since it evaluates the relevance of "place attachments" to understand migration processes. The geographical literature has extensively discussed on "place attachments" (aka "sense of place") since the mid-1970s (e.g. Relph 1976, Tuan 1977). Yet, with few exceptions, the analytical potential of this concept has to be explored in the study of international migration (Mendoza and Morén-Alegret 2013).

\section{Methods}

The paper is based on quantitative and qualitative data. As for the quantitative techniques, we use the May 2007 Survey "Migration, Place and the Employment in Valle de Chalco-Solidaridad (Estado de México)" (EMLE in its Spanish acronym) which was carried out by the Metropolitan Autonomous University. These data were complemented with qualitative information coming from thirty in-depth semi-structured interviews which were carried out at a later stage of the research process.

EMLE is a randomized closed-ended representative survey of 759 households from the municipality of Valle de Chalco-Solidaridad. Using probabilistic techniques, census blocks were randomly chosen from the cartography of the municipality by the census tracts. The 2007 EMLE was not specifically addressed to heads of the household, since it sought to collect migration information from all household members (plus a substantial range of 
everyday practices and opinions on places from people of both sexes and different ages).

The 2007 the EMLE questionnaire consisted of four parts. The first was a household roster that listed all household members at the time of the survey, in May 2007, and basic demographics for each person (e.g. sex, age, education level). A total of 759 households were surveyed, representing information on 3,488 individuals. Part two of the questionnaire specifically focused on US migration (first and last trips, work in the U.S., legal status and return). Specifically, out of 759 households, 146 had at least one member who had migrated to the U.S., representing $19.2 \%$ of the total numbers. This figure went down to $8.0 \%$ for those households with members who were in the U.S. at the moment of the survey. Most of the interviewees $(70.3 \%)$ had only made one trip, mainly in 2000-07 (half of the 203 US migrants made their first trip in this period). Part 3 of the questionnaire was specifically addressed to the heads of the household. Here data on the labour and migration trajectories of the household head and spouse were collected. Finally Part 4 took a geographical stance, with several questions on "place dependence" (e.g. places where they do everyday activities) and "place identity", revolving around opinions and feelings about the different places that formed migration trajectories.

\section{Explaining the Models: The Odds for International Migration}

The paper aims to assess the role of social networks in channelling urban emigration to the States. To do so, we constructed several logistic regression models designed to measure the probability of emigration, in which we take the household international migration (i.e. the presence of US immigrants and/or return migrants in the household) as a proxy for the existence of migrant social networks. This may help understand the way that these social networks operate, in the sense that we can compare patterns of migration behaviour depending on the fact of having (or not) migrant social networks in the household. Here we differentiate two types of households regarding migration: i. those with any sort of migrants (i.e. any member of the household who is now in the U.S., or has been in the past), and ii. households with return migrants. On this basis, we identified four distinct groups, depending on the type of household migration experience (i.e. households with/without US migration experience; households with/without return migrants). Out of 759 households, $19.2 \%$ had or had had a person who had participated in a migration stream to the U.S., and $11.7 \%$ had return migrants (Table 1).

The question on attachment to the U.S. which comes from a closed question is used as the dependent variable for constructing the logistic regression models. The dependent variable is constructed as a dichotomy variable from the possible answers. Only those who chose the phrase "If I could, I would live in the U.S." were considered to be would-be US migrants (1). The other place attachments (neutral -"I would like to visit the U.S., but I wouldn't live in the country" and negative -"I am not interested in the U.S.") were 
classified as non potential emigrants (0). Only $10.7 \%$ of all the interviewees said that they would migrate to the U.S., if the possibility came up (Table 1).

With the dependent variable being the probability of migration to the U.S., and the household US experience used as a grouping variable, the independent variables were classified into two groups: i. socio-demographic characteristics of the interviewed person; and ii. territorial and place variables. Then we suppose that migration differs according to age, education and marital status. Only $11.2 \%$ of all the interviewees had university studies, whereas the percentage of those who had not finished primary school amounted to $19.1 \%$. These figures are similar to the country as a whole (INEGI 2013). Married people dominate the survey, comprising more than half of all four groups. This is consistent with the average age of the survey, which is about 39-40 years in all cases (Table 1).

The different models for estimating the probabilities of migration to the U.S. allow us to identify differences in migration behaviour depending on household US experience. Following a classical approach in migration studies, some models only contemplate socio-demographic characteristics (plus the fact of having US migration experience in the household) as independent variables. For others we introduce territorial and place variables. This method of model construction implies two assumptions that need to be tested. First, in separating models according to the household experience, and the following networks theory and accumulative causation assumptions, we may think that emigration from households with emigration experience (either return or not) would have different characteristics from those without emigration. Secondly, controlled by territorial and place variables (home, Valle de Chalco-Solidaridad and birth place attachments), the hypothesis that those households in Mexico with higher territorial attachments in Mexico have lower probabilities of emigration to the U.S. can be tested.

Data show that the fact of having US migrants in the household increases the odds of international migration more than twofold (Table 2). These probabilities are even higher if the household contains return migrants (4.835 and 4.762; Table 3). The differences are minimal, however, when controlled by the three above mentioned territorial and place variables. This is to say that households that have relatives living in destination areas, or have members with experience in those areas, are more likely to send migrants than those who do not. In other words, the experience of international migration in the households facilitates further movement to the U.S. This is not new, as results are consistent with the large literature on migrant social networks. 
Table 1. Profile of the Interviewed Residents of Valle de Chalco-Solidaridad, by Type of Household

\begin{tabular}{|c|c|c|c|c|c|}
\hline & $\begin{array}{c}\text { All } \\
\text { Households }\end{array}$ & $\begin{array}{c}\text { Households } \\
\text { with } \\
\text { migrants } \\
\end{array}$ & $\begin{array}{c}\text { Households } \\
\text { without } \\
\text { migrants } \\
\end{array}$ & $\begin{array}{c}\text { Households } \\
\text { with return } \\
\text { migrants }\end{array}$ & $\begin{array}{c}\text { Households } \\
\text { without return } \\
\text { migrants } \\
\end{array}$ \\
\hline $\mathbf{N}$ & 759 & 146 & 613 & 89 & 670 \\
\hline \multicolumn{6}{|l|}{ Migration } \\
\hline \multicolumn{6}{|l|}{$\begin{array}{l}\text { International migrants } \\
\text { in households }\end{array}$} \\
\hline No & 80.8 & & & & \\
\hline Yes & 19.2 & & & & \\
\hline \multicolumn{6}{|l|}{$\begin{array}{l}\text { Return migrants in } \\
\text { households }\end{array}$} \\
\hline No & 88.3 & 39.0 & & & \\
\hline Yes & 11.7 & 61.0 & & & \\
\hline \multicolumn{6}{|l|}{$\begin{array}{l}\text { Socio-demographic } \\
\text { variables }\end{array}$} \\
\hline \multicolumn{6}{|l|}{$\operatorname{Sex}$} \\
\hline Female & 65.1 & 58.2 & 66.7 & 56.2 & 66.3 \\
\hline Male & 34.9 & 41.8 & 33.3 & 43.8 & 33.7 \\
\hline \multicolumn{6}{|l|}{ Education } \\
\hline $\begin{array}{c}\text { No education or } \\
\text { unfinished primary }\end{array}$ & 19.1 & 19.2 & 19.1 & 18.0 & 19.3 \\
\hline Primary education & 34.9 & 37.0 & 34.4 & 37.1 & 34.6 \\
\hline Secondary education & 34.8 & 37.0 & 34.3 & 36.0 & 34.6 \\
\hline University and above & 11.2 & 6.8 & 12.2 & 9.0 & 11.5 \\
\hline \multicolumn{6}{|l|}{ Marital status } \\
\hline $\begin{array}{l}\text { Single (never } \\
\text { married) }\end{array}$ & 15.7 & 16.6 & 15.5 & 16.9 & 15.6 \\
\hline Married & 57.7 & 56.6 & 57.9 & 61.8 & 57.1 \\
\hline $\begin{array}{l}\text { Cohabitation (no } \\
\text { married) }\end{array}$ & 16.8 & 15.9 & 17.0 & 13.5 & 17.2 \\
\hline Widow / Divorced & 9.9 & 11.0 & 9.6 & 7.9 & 10.1 \\
\hline $\begin{array}{l}\text { Age (years at survey / } \\
\text { average) }\end{array}$ & 39.7 & 39.0 & 39.9 & 38.8 & 39.8 \\
\hline \multicolumn{6}{|l|}{$\begin{array}{l}\text { Territorial and place } \\
\text { variables }\end{array}$} \\
\hline \multicolumn{6}{|l|}{ Place of birth } \\
\hline Mexico City & 56.0 & 50.7 & 57.3 & 51.7 & 56.6 \\
\hline Elsewhere in Mexico & 44.0 & 49.3 & 42.7 & 48.3 & 43.4 \\
\hline \multicolumn{6}{|l|}{ Home attachment } \\
\hline Weak & 33.4 & 37.5 & 32.4 & 36.8 & 32.9 \\
\hline Neutral & 44.9 & 45.4 & 44.9 & 47.1 & 44.7 \\
\hline Strong & 21.7 & 17.4 & 22.7 & 16.1 & 22.4 \\
\hline \multicolumn{6}{|l|}{$\begin{array}{l}\text { Attachment to Valle } \\
\text { Chalco }\end{array}$} \\
\hline Weak & 43.0 & 54.3 & 41.3 & 55.2 & 41.4 \\
\hline Neutral & 31.6 & 24.5 & 32.7 & 23.0 & 32.8 \\
\hline Strong & 25.4 & 21.3 & 26.0 & 21.8 & 25.9 \\
\hline \multicolumn{6}{|l|}{$\begin{array}{l}\text { Attachment to the place } \\
\text { of origin }\end{array}$} \\
\hline Weak & 32.7 & 32.8 & 32.7 & 32.5 & 32.8 \\
\hline Neutral & 42.6 & 45.3 & 42.0 & 45.0 & 42.3 \\
\hline Strong & 24.7 & 21.9 & 25.3 & 22.5 & 25.0 \\
\hline \multicolumn{6}{|l|}{ Attachment to the US } \\
\hline Weak & 39.4 & 34.3 & 40.1 & 36.9 & 39.7 \\
\hline Neutral & 49.9 & 36.7 & 51.8 & 34.5 & 51.9 \\
\hline Strong & 10.7 & 28.9 & 8.1 & 28.6 & 8.4 \\
\hline
\end{tabular}

Source: EMLE (May 2007) 
Table 2. Logistic Regression Models for Migration to the U.S., by Type of Household (all migrants)

\begin{tabular}{|c|c|c|c|c|c|c|}
\hline 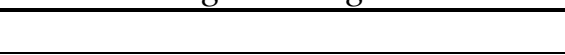 & All households & & Households with migrants & & Households without migrants & \\
\hline & Model 1 & Model 2 & Model 3 & Model 4 & Model 5 & Model 6 \\
\hline & $\exp (\beta)$ & $\exp (\beta)$ & $\exp (\beta)$ & $\exp (\beta)$ & $\exp (\beta)$ & $\exp (\beta)$ \\
\hline \multirow{2}{*}{\multicolumn{7}{|c|}{\begin{tabular}{|l|} 
Migration \\
\end{tabular}}} \\
\hline \multicolumn{4}{|l|}{ International migrants in househoulds } & & & \\
\hline No & ref & ref & & & & \\
\hline Yes & $2.565 * * *$ & $2.713^{* * *}$ & & & & \\
\hline \multicolumn{7}{|l|}{ Socio-demographic variables } \\
\hline \multicolumn{7}{|l|}{$\operatorname{Sex}$} \\
\hline Males & ref & ref & ref & ref & ref & ref \\
\hline Females & $0.527 * *$ & $0.600^{*}$ & 1.199 & 1.086 & $0.486 * *$ & $0.485 * *$ \\
\hline \multicolumn{7}{|l|}{ Education } \\
\hline Unfinished primary & ref & ref & ref & ref & ref & ref \\
\hline Primary education & 1.309 & 1.056 & $4.403 *$ & 3.732 & 0.703 & 0.645 \\
\hline Secondary education & 1.104 & 0.993 & $9.753^{* *}$ & $10.445^{* *}$ & 0.594 & 0.460 \\
\hline University and above & 0.988 & 0.679 & $15.358 * *$ & $28.533 * *$ & 0.398 & $0.207 * *$ \\
\hline \multicolumn{7}{|l|}{ Marital status } \\
\hline Single & Ref & ref & ref & ref & ref & ref \\
\hline Married & $0.533 *$ & $0.482 *$ & 1.779 & 2.698 & $0.275 * *$ & $0.260 * *$ \\
\hline Cohabitation (no married) & 0.688 & 0.631 & 0.342 & 0.357 & 0.663 & 0.591 \\
\hline Widow / Divorced & 0.736 & 0.697 & 1.382 & 1.759 & 0.553 & 0.559 \\
\hline Age & 0.992 & 0.992 & 1.030 & 1.035 & 0.974 & 0.978 \\
\hline
\end{tabular}




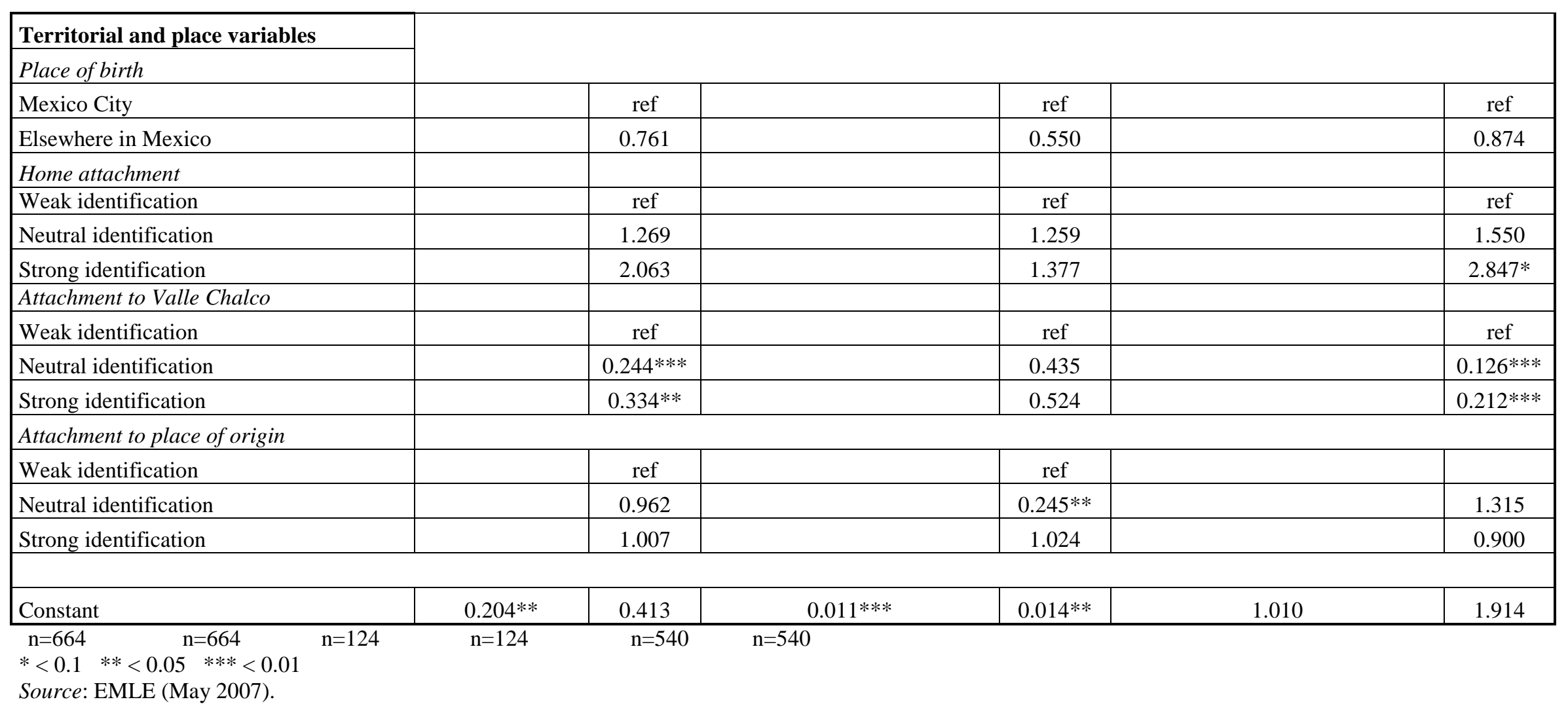


Table 3. Logistic Regression Models to the U.S., by Type of Household (Return Migrants)

\begin{tabular}{|c|c|c|c|c|c|c|}
\hline 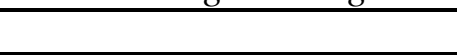 & All & households & Households with return migrants & & Households without return migrants & \\
\hline & Model 7 & Model 8 & Model 9 & Model 10 & Model 11 & Model 12 \\
\hline & $\exp (\beta)$ & $\exp (\beta)$ & $\exp (\beta)$ & $\exp (\beta)$ & $\exp (\beta)$ & $\exp (\beta)$ \\
\hline \multicolumn{7}{|l|}{ Migration } \\
\hline \multicolumn{7}{|l|}{ Return migrants in households } \\
\hline No & ref & ref & & & & \\
\hline Yes & $4.835^{* * * *}$ & $4.762 * * *$ & & & & \\
\hline \multicolumn{7}{|l|}{ Socio-demographic variables } \\
\hline \multicolumn{7}{|l|}{$\operatorname{Sex}$} \\
\hline Males & ref & ref & ref & ref & ref & ref \\
\hline Females & $0.610^{*}$ & $0.597 *$ & 1.202 & 1.159 & $0.490 * *$ & $0.489 * *$ \\
\hline \multicolumn{7}{|l|}{ Education } \\
\hline Unfinished primary & ref & ref & ref & ref & ref & ref \\
\hline Primary education & 1.125 & 1.144 & $5.835^{*}$ & $6.738^{*}$ & 0.702 & 0.603 \\
\hline Secondary education & 1.315 & 1.110 & $20.312 * * *$ & $60.511^{* * *}$ & 0.697 & 0.541 \\
\hline University and above & 0.812 & 0.741 & $25.001^{* *}$ & $172.307 * * *$ & 0.396 & $0.210^{* *}$ \\
\hline \multicolumn{7}{|l|}{ Marital status } \\
\hline Single & ref & ref & ref & ref & ref & ref \\
\hline Married & $0.442 *$ & $0.448^{*}$ & 2.033 & 5.558 & $0.251 * * *$ & $0.236^{* * *}$ \\
\hline Cohabitation (no married) & 0.650 & 0.619 & 0.402 & 0.554 & 0.603 & 0.473 \\
\hline Widow / Divorced & 0.793 & 0.764 & 3.239 & 6.739 & 0.428 & 0.398 \\
\hline Age & 0.993 & 0.995 & 1.112 & $1.091 *$ & 0.979 & 0.981 \\
\hline
\end{tabular}




\begin{tabular}{|c|c|c|c|c|c|c|}
\hline \multirow{2}{*}{\multicolumn{7}{|c|}{\begin{tabular}{|l} 
Territorial and place variables \\
Place of birth \\
\end{tabular}}} \\
\hline & & & & & & \\
\hline \multicolumn{7}{|l|}{ Mexico City } \\
\hline Elsewhere in Mexico & & 0.722 & & 0.398 & & 0.809 \\
\hline \multicolumn{7}{|l|}{ Home attachment } \\
\hline Weak identification & & ref & & ref & & ref \\
\hline Neutral identification & & 1.136 & & 0.831 & & 1.428 \\
\hline Strong identification & & 1.931 & & 1.535 & & $2.728^{*}$ \\
\hline \multicolumn{7}{|l|}{ Attachment to Valle Chalco } \\
\hline Weak identification & & ref & & ref & & ref \\
\hline Neutral identification & & $0.277 * * *$ & & 0.929 & & $0.117^{* * *}$ \\
\hline Strong identification & & $0.349 * * *$ & & 1.440 & & $0.220 * * *$ \\
\hline \multicolumn{7}{|l|}{ Attachment to place of origin } \\
\hline Weak identification & & ref & & ref & & ref \\
\hline Neutral identification & & 1.011 & & $0.103^{* *}$ & & 1.319 \\
\hline Strong identification & & 1.040 & & 0.844 & & 0.865 \\
\hline \multirow[t]{2}{*}{ Constant } & $0.208^{*}$ & 0.365 & $0.002 * * *$ & $0.001^{* *}$ & 0.958 & 1.886 \\
\hline & $\mathrm{n}=664$ & $\mathrm{n}=664$ & $\mathrm{n}=78$ & $\mathrm{n}=78$ & $\mathrm{n}=586$ & $\mathrm{n}=586$ \\
\hline
\end{tabular}

$*<0.1 \quad * *<0.05 \quad * * *<001$

Source: EMLE (May 2007). 


\section{The Irrelevance of "Place"}

In the last section, we indicated that territorial and place variables played no significant role in the models, pointing to a general picture of "placelessness". This might reflect the poor working and living conditions, and the settlement history of the municipality of our study (Lindón 2005, Mendoza 2009) which indeed may be the case for many low-income suburbs in Mexican cities. Urban sprawl, lack of services, poor infrastructure, and precarious jobs are all reasons for low territorial attachment and emigration.

The idea of "placelessness" is being reinforced by information in the interviews. They generally agree on the lack of services in the area. Indeed, the only clear attachment which comes out in the interviews is home. This should be understood in the context of first local residents fighting to get their properties legalised (in many cases houses were built out of the state control), and basic services, such as water. Apart from recognizing the poor quality of the services, interviewees also point to the fact that, despite some urban improvement, Valle de Chalco-Solidaridad has gone through a process of rapid urban growth that is associated with crime and loss of any Atmosphere of comradeship normally built in adversity. For instance, an interviewee told us that Valle de Chalco-Solidaridad has changed to feel less secure and this is because of the "people who have arrived from other municipalities. They rent. Who knows what habits they have, or what tricks they know".

In this context of poor urban infrastructure, scarce work opportunities, inmigration from other parts of Greater Mexico City, and increasing crime, it is not surprising that many interviewees do not develop strong attachments to Valle de Chalco residents, keeping their relationships in the municipality to family and relatives. With few friends in town (only $47.3 \%$ of those surveyed declared that they had friend in Valle de Chalco, aside from their family), the idea of building a sense of community becomes remote.

\section{Family versus Independent Migration: The Lack of Expansion Networks}

In this context of lack of confidence and poor role of "place", it is not surprising that networks are constructed following family lines, instead of being shared by the community. The following extract illustrates the example of a working mother who cannot afford her current situation, and so she wants her son to follow his father to the States, instead of causing her further economic stress. This interviewee also illustrates the reality of many working poor on the periphery of large Latin American cities, for whom there is no escape from poverty:

Does your son work?

No, he is about to finish secondary school.

Wouldn't you like your son to continue studying? 
I cannot afford it. If he wants to study, this would be his choice. I'd rather he joined his father in USA (Luisa, 49, cleaner).

Since Valle de Chalco-Solidaridad is a recently created municipality, many families are split between their (rural) origin community and Greater Mexico City. In other words, for many their "community" is located in the rural areas where their family comes from. Indeed literature has shown that occasionally social networks that are used by Mexico City migrants in the US trace their roots back to rural areas (see, for instance, Rivera-Sánchez 2007, López and Runsten 2004). The following interview extract illustrates this pattern.

\section{When did you leave your hometown?}

I left it when I was 11 years old, with my father. Living conditions were tough down there (...) I am from a rural Oaxacan community. We had been here before for short periods, but we finally decided to move permanently to Mexico City.

We saw in your questionnaire that you had been to LA....

Yes. I've been to the States three times. The first time I went to LA was because I had an uncle. He had told me his wage. I came back to visit my family after two years, and I went back to the same job in LA, as a wetback. Finally I stayed there for five years. I decided to come back definitely to Mexico because of my family (Rafael, 41, shopkeeper).

Because information is not shared between neighbours, families organize their own "autonomous" routes; some of them having roots in rural areas, according to Rafael. There are no fixed circuits between Valle de ChalcoSolidaridad and the US destinations (as we can see for rural communities, Goldring 1992, Smith 1998). Indeed the survey analysis of the states to which the residents of the municipality migrate displays a wide range of options. Therefore half of the US migrants chose classical destinations (Texas, California and Illinois), but the other head to emergent states, such as Florida, Arizona, and the Carolinas. This dispersion has also been shown recently elsewhere in the literature (e.g. Massey 2008). In explaining this pattern, some authors argue that socials networks that are constructed by immigrants reach a point of saturation regarding employment and housing opportunities in traditional reception places (Light and Scheven 2008), so immigrants disperse. Our evidence suggests that the dispersion is also a result of the actions of migrant social networks, since they are organized along family lines, sometimes tracing back their roots to rural areas in Mexico.

\section{Male Flows and Female Independent Networks}

When migration decisions are taken within families, men generally take the lead in initiating international migration, as we saw in the example of Luisa 
in a past paragraph. Even though flows are greatly dominated by men (e.g. Massey et al. 2002, Aysa and Massey 2004), women already constitute $46.3 \%$ of the total Mexican-born immigrants in the US, according to the 2010 American Community Survey (US Bureau of Census, 2012). In line with the literature, according to our data, women have $40 \%$ less probability than men of deciding on an international move (Models 1 and 2 in Table 2; Models 7 and 8 in Table 3). Beyond that, our interest lies in exploring how social networks may help overcome (or not) gender barriers for migration, and evaluate if urban networks are organised along sex lines.

Therefore, when observing the odds of female international migration in the models depending on the household migration experience, we observe remarkable differences: Sex is not significant for households with migrants, whether they are return migrants or not, whereas in those without migration experience the variable is significant (Tables 2 and 3). For the latter group, the probability of migration for females is almost half that observed for men.

The next question to answer is why the variable "sex" is not significant for households with migrants. It seems that having migrants in a household helps women to emigrate. Maybe this is related to the role of social networks for urban migrants, which may operate in ways different to those of rural settings, with urban females having more autonomous social networks in cities, and being less dependent on the more numerous male networks. In fact, differences in the construction of immigrant's social networks by gender have long been documented in literature (e.g. Menjívar 2000, Avenarius 2009).

What the survey suggests is corroborated by our interviews. Out of 30 interviews, we found two examples of female-independent networks. This is the case of Alma, 20 years old, who told us about her mother's and sister's emigration experience. Both of them are currently living in the States. In her own words:

How did your mother decide to migrate to the States?

Because of my sister who has been living in the States for eight years.

Did your sister support her financially to cross the border?

Yes, her husband did.

Was your sister the first of the family to leave Mexico?

Yes.

How did she manage?

A female cousin helped her out. Emigrating came up as a possibility for her and she took the chance (Alma, 20, housekeeper). 


\section{Education-Shaped Networks}

Similarly to "sex", the variable "education" also shows different indicators, depending on the US household experience (yet on the opposite direction). For households with US migrants, education seems to be crucial to understanding the urban international out-flows (Tables 2 and 3). With the exception of Model 4 for students with primary education, the models of households with migrants always show that the likelihood of emigration to the U.S. increases with years of education (up to university studies). Thus the odds of those with primary schooling are higher than for those with no studies or unfinished primary education. For those with a university education, the probability of emigration is even higher, although we have to take a cautious approach here since the number of those with university diplomas is low. For the households without migrants, education does not generally play a significant role in explaining the probabilities of out-migration.

Our data suggest that formal education only has an effect on emigration when migrant social networks are in operation, with more educated migrants minimizing the risks of an (irregular) international crossing. By contrast, McKenzie and Rapoport (2007) found that the strengthening of social networks lowered the economic costs of emigration, and consequently expanded migration to less educated groups. In contrast, in communities with weak networks, a positive selection toward the better educated, who have a greater probability of making an international move, was observed.

Qualitative data also points to the direction of our survey. José Manuel, a university student, was reluctant to migrate. He finally did because his family insisted and he had an extensive support network in the US. After an unsuccessful try, he is currently pursuing studies at university:

I've got a brother in New Jersey. He told me that I could join him, but I decided not to do so. I went to university. After a while, my sister decided to go to the States (...) My family insisted on me going with her, but I was not interested. (...) I wanted to finish university (...). Finally I decided to go North, and my family was happy, because I accompanied my sister on this unsafe risky trip (...). Later, the migra sent us back (José Manuel, 21, student).

\section{Conclusions}

These results shed new light on the mechanism through which social networks operate in urban settings. Even if a municipality that is very homogeneous in terms of (high levels of) poverty and (low) employment opportunities, we found variations on the socio-demographic profile of the would-be emigrants to the US depending on the household's social networks. In other words, not everyone is susceptible to emigration, despite structural 
adjustments in the economy and a general landscape of relative privation. The picture depicted of the Mexican urban emigrant in our survey is far beyond the images of a lowly-educated young male that emerges from the rural area literature. Our data suggest that urban females may organize their own autonomous social networks, and that the higher educated in cities value their future in Mexico (and only try the adventure further north when they have the support of social networks).

As for territorial attachments, both the survey and the interviews show a general picture of "placelessness", with practically all the territorial and place variables playing no significant role in the models. Indeed, interviewees have a very low opinion of the U.S., which suggests that international migrants from urban cities are not lured by positive images, but by economic factors. This reflects the settlement history of the municipality of our study which may be the case for many low-income suburbs in Mexican cities. Urban sprawl, lack of services, poor infrastructure, and precarious jobs are all reasons for low territorial attachment and emigration. Nevertheless the migration experience remarkably increases positive views on the U.S., with individuals in households with international emigration experience having four times more favourable opinions on the States than those without emigration. This may encourage further emigration. Indeed these data challenge previous evidence on the inapplicability of the cumulative causation theory to urban-origin Mexican migration (Fussell and Massey 2004), even if cumulative causation seems to occur within the limits of the household and the family, and does not expand to the municipality.

\section{References}

Aguilar AG (2002) Las mega-ciudades y las periferias expandidas: Ampliando el concepto en Ciudad de México [Megacities and expanded peripheries: Expanding the concept in Mexico City]. EURE Revista Latinoamericana de Estudios Urbano Regionales 28(85): 121-149.

Avenarius CB (2009) Immigrant networks in new urban spaces: Gender and social integration. International Migration 50(6): 25-55.

Aysa M, Massey DS (2004) Wifes left behind: The labor market behavior of women in migrant communities. In J Durand, DS Massey (Eds) Crossing the border: Research from the Mexican Migration Project, 131-146. New York: Russell Sage.

Delgado-Wise R, Márquez Covarrubias H (2007) The reshaping of Mexican labor exports under NAFTA: Paradoxes and challenges. International Migration Review 41(3): 656-679.

Flores NY, Hernández-León R, Massey DS (2004) Social capital and emigration from rural and urban communities. In J Durand, DS Massey (Eds) Crossing the border: Research from the Mexican Migration Project, 184-200. New York: Russell Sage.

Fussell E, Massey DS (2004) The limits to cumulative causation: International migration from Mexican urban areas. Demography 41(1): 151-171. 
Goldring L (1992) Diversity and community in transnational migration: A comparative study of two Mexico-U.S. migrant circuits. Doctoral thesis. Cornell University.

Hernández-León R (2008) Metropolitan migrants: The migration of urban Mexicans to the United States. Berkeley, CA: University of California Press.

INEGI (2013) Censo de Población y Vivienda 2010 [2010 Population and Housing Census]. Instituto Nacional de Estadística y Geografía, Mexico City. DOI= http://www.inegi.gob.mx.

Light I, von Scheven E (2008) Mexican migration networks in the United States, 1980-2000. International Migration Review 42(3): 704-728.

Lindón A (1999) De la trama de la cotidianidad a los modos de vida urbanos: El Valle de Chalco [From everyday narratives to urban ways of living: El Valle de Chalco]. Mexico City: El Colegio de México \& El Colegio Mexiquense.

Lindón A (2005) El mito de la casa propia y las formas de habitar [The myth of home ownership and ways of inhabiting]. Scripta Nova. Revista Electrónica de Geografía y Ciencias Sociales 194. DOI= http://www.ub.es/geocrit/sn/sn-19420.htm.

López FH, Runsten D (2004) El trabajo de los mixtecos y los zapotecos en California: Experiencia rural y urbana [Mixtec and Zapotec people working in California: Rural and urban experiences]. In J Fox, G Rivera-Salgado (Eds) Indígenas mexicanos migrantes en los Estados Unidos, 277-309. Mexico City: Cámara de Diputados LIX Legislatura, University of California at Santa Cruz, Universidad Autónoma de Zacatecas and Miguel Ángel Porrúa.

Marcelli EA, Cornelius W (2001) The changing profile of Mexican migrants to the United States. New evidence from California and Mexico. Latin American Research Review 36(3): 105-131.

Massey DS (2008) New faces in new places: The changing geography of American immigration. New York: Russell Sage Foundation.

Massey DS, Alarcón R, Durand J, González H (1987) Return to Aztlan: The social process of international migration from Western Mexico. Berkeley, CA: University of California Press.

Massey DS, Durand J, Malone NJ (2002) Beyond smoke and mirrors: Mexican immigration in an era of economic integration. New York: Russell Sage Foundation.

McKenzie D, Rapoport H (2007) Self-selection patterns in Mexico-US migration: The role of migration networks. World Bank Policy Research Working Paper 4118. DOI= http://www.biu.ac.il

Mendoza C (2009) La emergencia de la migración internacional en la periferia empobrecida de la ciudad de México: Valle de Chalco-Solidaridad, Estado de México [The emergence of international migration in Mexico City's poor periphery: Valle de Chalco-Solidaridad, Estado de México]. Migraciones Internacionales 5(2): 5-37.

Mendoza C, Morén-Alegret R (2013) Exploring methods and techniques for the analysis of senses of place and migration. Progress in Human Geography 37(6): 762-785.

Menjívar C (2000) Fragmented ties: Salvadoran immigrant networks in America. Berkeley, CA: University of California Press.

Relph E (1976) Place and placelessness. London: Pion. 
Rivera-Sánchez L (2007) La formación y dinámica del circuito migratorio MixtecaNueva York-Mixteca: Los trayectos internos e internacionales [Creation and dynamics of Mixteca-New York-Mixteca circuit]. Norteamérica 2(1): 171-203.

Roberts BR, Frank F, Lozano F (1999) Transnational migrant communities and Mexican migration to the US. Ethnic and Racial Studies 22(2): 238-266.

Smith RC (1998) Transnational localities: community, technology and the politics of membership within the context of Mexico and U.S. migration. In MP Smith, LE Guarnizo (Eds) Transnationalism from below, 196-238. New Brunswick, NJ: Transaction Publishers.

Tuan Y-F (1977) Space and place: The perspectives of experience. Minneapolis, MN: University of Minnesota Press.

US Bureau of Census (2012) 2010 American Community Survey. Washington, DC: US Bureau of Census. DOI= https://www.census.gov. 
